\title{
Prevalence and determinants of one month hand pain and hand related disability in the elderly (Rotterdam study)
}

\author{
S Dahaghin, S M A Bierma-Zeinstra, M Reijman, H A P Pols, J M W Hazes, B W Koes
}

Ann Rheum Dis 2005;64:99-104. doi: 10.1136/ard.2003.017087

See end of article for authors' affiliations

Correspondence to: S Dahaghin, Department of General Practice, Room Ff 325, Erasmus Medical Centre, PO Box 1738, 3000 DR Rotterdam, Netherlands;

s_dahaghin@yahoo.com

Accepted 10 March 2004
Objective: To study the prevalence of hand pain and hand disability in an open population, and the contribution of their potential determinants.

Methods: Baseline data were used from 7983 participants in the Rotterdam study (a population based study in people aged $\geqslant 55$ years). A home interview was used to determine the presence of hand pain during the previous month, rheumatoid arthritis, osteoarthritis in any joint, diabetes, stroke, thyroid disease, neck/shoulder pain, gout, history of fracture in the past five years, and Parkinson's disease, as well as age, sex, and occupation. Hand disability was defined as the mean score of eight questions related to hand function. Body mass index was measured and hand $x$ rays were taken.

Results: The one month period prevalence of hand pain was $16.9 \%$. The prevalence of hand disability was 13.6\%. In univariate analysis for hand pain, rheumatoid arthritis had the highest explained variance $\left(R^{2}\right)$ and odds ratio. For hand disability, aging showed the highest explained variance and Parkinson's disease had the highest odds ratio. All determinants together showed an explained variance of $19.8 \%$ for hand pain and $25.2 \%$ for hand disability. In multivariate analysis, positive radiographic hand osteoarthritis was a poor explanation for hand pain $\left(R^{2}=0.5 \%\right)$ or hand disability $\left(R^{2}=0\right)$.

Conclusions: The contribution of available potential determinants in this study was about $20 \%$ for hand pain and $25 \%$ for hand disability in an unselected population of elderly people. Thus a greater part of hand pain/hand disability remains unexplained.
$\mathrm{T}$ he life expectancy in western societies has increased over the last decades. However, many people reach old age with increasing chronic pain and disability. In a recent United Kingdom survey, the incidence of self reported pain was $50 \%$, or $46.5 \%$ when adjusted to the whole UK population. ${ }^{1}$ The three most common causes of chronic pain are musculoskeletal disorders, neuropathic disorders, and tumours. ${ }^{2}$

The estimated prevalence of distal upper limb pain varies depending on the severity and duration of the symptoms. The reported prevalence of hand or wrist pain varies between 3\% and $26 \%$ of the general population. ${ }^{3-5}$

Disability is reflected in difficulties in performing activities of daily living, of which hand function is an important aspect. The ability to use the hand effectively depends on anatomical integrity, mobility, muscle strength, sensation, coordination, and absence of pain..$^{6-8}$ Although chronic pain and disability have received much attention, less is known about hand pain and hand disability specifically. To achieve effective management of pain and disability in the hand, the potential determinants need to be understood. Rheumatoid arthritis, other types of chronic arthritis, osteoarthritis, carpal tunnel syndrome, different forms of tendinitis in the hand and wrist, referred pain from the neck or shoulder, diabetes, other peripheral neuropathies, fractures in the hand and wrist, fibromyalgia, stroke, thyroid disease, gout, Parkinson's disease, obesity, manual occupation, age, and sex are all potentially related to hand pain or hand disability. ${ }^{3-21}$ However, the interrelations of most of these factors have not been explored. Our aim in this study was therefore to investigate the prevalence of hand pain and hand disability in the elderly, and the contribution of several potential determinants to these problems.

\section{METHODS}

\section{Study population}

The study was conducted as a part of the Rotterdam study, a prospective population based cohort study of determinants and prognosis of chronic diseases in the elderly. The medical ethics committee of the Erasmus Medical Centre approved the study, and written informed consent was obtained from all participants. The baseline measurements were made between April 1990 and July 1993. The complete study design has been described previously. ${ }^{22}$ The focus is on cardiovascular, neurogeriatric, ophthalmological, and locomotor diseases. All inhabitants of Ommoord (a suburb of Rotterdam) who were aged 55 years and over were invited to participate. In all, 7983 participants were examined (a response rate of $78 \%$ ). At baseline, trained interviewers undertook an extensive home interview on demographic characteristics, medical history, risk factors for chronic diseases, and the use of medicines. To investigate the occurrence of hand pain and disability and the contribution of potential determinants, we used data from the home interview with the baseline population. We also used height and weight to calculate body mass index (BMI) and we assessed hand $x$ rays that were taken at the centre at baseline. To study the influence of radiographic hand osteoarthritis, we used available data from a subsample of the study population (3906 individuals).

\section{Measurements}

\section{Hand pain}

Trained interviewers asked participants the following questions about hand pain during the home interview: (1) Did you have pain in the right (left) hand during the last month? (2) How long did you have pain? If pain was present, its duration was determined as: less than one month; one to three months; three to six months; six months to one year; one to five years; or more than five years.

Abbreviations: GEE, generalised estimating equations; $H A Q$, health assessment questionnaire; K-L, Kellgren-Lawrence grade 


\section{Hand disability}

The Rotterdam study investigated various aspects of disability. During the home interview, disability was assessed using the Stanford health assessment questionnaire (HAQ). The HAQ assesses disability by eight components, composed of 24 questions. To assess hand disability, we used eight questions concerning hand function from the HAQ questionnaire (appendix 1). Each question scored from 0 to 3, representing normal (no difficulty) $=0$, some difficulty $=1$, much difficulty $=2$, unable to do $=3$. Dependence on equipment or physical assistance was ignored as it represents residual disability after compensatory efforts. Of the components with more than one question related to hand function (grip, eating), the highest score was used (as in the original disability index). ${ }^{23-25}$ The scores were averaged to form an overall hand disability score on a scale from 0 (no hand disability) to 3 (completely hand disabled). A mean score of 0.50 or greater was defined as the presence of hand disability, which means moderate to complete hand disability. This cut off point was also used for the overall disability index.

\section{Determinants}

Self reported determinants were assessed for their contribution to the presence of hand pain and disability. A history of rheumatoid arthritis, osteoarthritis in any joint, diabetes, stroke, thyroid disease, neck and shoulder pain during the previous month, gout, history of fracture in the past five years (hand/wrist), or Parkinson's disease was collected by interview at baseline, along with age, sex, and current or last occupation. In addition, hand pain was considered as a determinant of hand disability. Age was analysed as a categorised variable in two groups-55 to 69 years and 70 years or more-and also as a continuous variable. Occupation was classified according to the Central Office of Statistics Netherlands (CBS) code $1984 .^{26}$ A comparison was made between participants with a history of manual occupation versus participants with all other types of occupation.

A cut off point of $30 \mathrm{~kg} / \mathrm{m}^{2}$ or higher for the BMI was used as a measure of obesity.

We used baseline data on the presence of complaints in the other joints during the previous month to evaluate the coexistence of other joint complaints with hand pain.

Two trained assessors (SD, UC) scored 3906 of the baseline hand $x$ rays (anteroposterior view) in 2002. This selection was chosen for another study aim and included all participants available for follow up six years later. The readers were blinded for other data such as clinical or demographical variables. Radiographs were scored for six individual radiographic features of osteoarthritis in the distal interphalangeal joint (DIP), first interphalangeal joint (IP), proximal interphalangeal joint (PIP), first carpometacarpal joint ( $\mathrm{CMCl}$ ), and trapezio-scaphoid joint (TS). Osteophytes were differentiated into three grades (small, moderate, large), while joint space narrowing, sclerosis, cysts, lateral deformity, and cortical collapse were scored as either present or absent. Lateral deformity was defined as malalignment of at least $15^{\circ}$ (modified Kallman score)..27 Definite radiographic osteoarthritis for each joint was defined as a Kellgren-Lawrence (K-L) grade of 2 or more (appendix 2). Three groups of hand joints were defined, and a group was considered positive if at least one joint in the group had a $\mathrm{K}$-L grade of $\geqslant 2$. Hand osteoarthritis was defined as the presence of a K-L grade of $\geqslant 2$ in two of three groups of hand joints (DIP/IP, PIP, and CMC1/TS) on the left or right side or both, a definition of radiographic hand osteoarthritis which has been used in other studies. $^{28} 29$

To measure interobserver reliability of the scoring, the two assessors (SD, UC) both scored a random subset of 205 radiographs independently of each other.

\section{Statistical analysis}

The $\kappa$ statistic was used to measure the degree of agreement between the two assessors for radiographic osteoarthritis ( $\mathrm{K}-\mathrm{L} \geqslant 2$, binary measurement).

Prevalence data were calculated for men and women separately. Univariate logistic regression analysis was used initially to examine associations between hand pain and disability and available potential determinants. Associations were expressed as odds ratios (OR) with 95\% confidence intervals (CI) and as explained variance $\left(R^{2}\right)$. In a multivariate logistic regression model, we analysed the total contributions of the available determinants with significant univariate relations ( $p$ value $<0.2$ ) to the hand pain on the right or left side or to hand disability.

In a subgroup of 3906 subjects for whom we had data on radiographic hand osteoarthritis, we studied the additional contribution of this variable (right/left) to hand pain or hand disability, using multivariate logistic regression analysis.

In addition, we used logistic regression for repeated measurement (generalised estimating equations, GEE) to take into account the contribution of side specific determinants such as shoulder pain, history of fracture (hand/wrist), and radiographic hand osteoarthritis on the right or left side with regard to hand pain on the same side (SAS PROC GENMOD)..$^{30}$

SPSS (version 10) and SAS (version 6.12) programs were used for all analyses.

\section{RESULTS}

Table 1 shows the baseline characteristics of the study population. Mean age was 70.6 years and $61.1 \%$ were women. The subgroup $(n=3906)$ was younger, with a mean age of 66.6 years, and $58.3 \%$ were women.

Interobserver reliability between the two assessors for scoring $x$ rays ( $K-\mathrm{L} \geqslant 2$, dichotomous variables) expressed by the $\kappa$ statistics was 0.68 for the left hand and 0.77 for the right hand.

\section{Hand pain}

The one month period prevalence of hand pain (left/right) was $16.9 \%$ (9.7\% in men and $21.6 \%$ in women); $97.2 \%$ of the participants had suffered from hand pain for more than one month, and $42.9 \%$ for more than five years. A much greater percentage of people with hand pain than without reported complaints in other joints $(71.6 \% \quad v \quad 41.3 \%)$. Univariate analysis showed that the prevalence of hand pain was not significantly changed in people aged 70 years and older compared with the 55 to 69 year age group (OR $=1.02(95 \%$ CI, 0.90 to 1.15$)$ ). In additional analysis, no change resulted when age was considered as a continuous variable or in

Table 1 Baseline characteristics of the total study population and the subgroup

\begin{tabular}{lll}
\hline Characteristic & $\begin{array}{l}\text { Whole population } \\
\text { (n=7983) }\end{array}$ & $\begin{array}{l}\text { Subgroup } \\
\text { (n=3906) }\end{array}$ \\
\hline Female & $61.1 \%$ & $58.3 \%$ \\
Age (years) (mean (SD)) & $70.6(9.8)$ & $66.6(7.3)$ \\
BMI (kg/m ${ }^{2}$ ) (mean (SD)) & $26.3(3.7)$ & $26.3(3.6)$ \\
Disability index* & $34.1 \%$ & $20.2 \%$ \\
Hand disability & $13.6 \%$ & $5.8 \%$ \\
Hand pain (left/right) & $16.9 \%$ & $16.8 \%$ \\
Any other joint complaints $†$ & $46.4 \%$ & $46.3 \%$ \\
\hline \multirow{2}{*}{ *A score of 0.5 or greater measured by health assessment questionnaire } \\
(HAQ). \\
†Neck, shoulder, elbow, low back, hip, knee, foot pain (right and/or \\
left). \\
BMl, body mass index.
\end{tabular}


narrower bands. Hand pain occurred more often in women $(\mathrm{OR}=2.6(2.2$ to 3.0$))$.

Rheumatoid arthritis showed the highest relation $(\mathrm{OR}=12.4)$ and the highest explained variance $\left(R^{2}\right)$ in the univariate analysis for hand pain, followed by pain in the neck/shoulder region, osteoarthritis in any joints, and female sex. Thyroid disease, obesity (BMI $\geqslant 30)$, a history of fracture, diabetes, and manual occupation each had an $R^{2}$ of less than $1 \%$. Gout, Parkinson's disease, stroke, and age did not explain any variance in the univariate model $\left(R^{2}=0\right)$. All determinants showing a relation with a p value $<0.2$ in the univariate analysis had a combined $R^{2}$ of $19.8 \%$ for hand pain. Associations of available determinants for hand pain in the univariate and multivariate analysis (OR, 95\% CI, $R^{2}$ ) are presented in table 2 .

\section{Hand disability}

The prevalence of hand disability was $13.6 \%$ (7.2\% in men and $17.8 \%$ in women). This was increased in people aged 70 years and older compared with those in the relatively younger age group ( $\mathrm{OR}=6.4$ (95\% CI, 5.4 to 7.6$)$ ). Hand disability was more common in women ( $\mathrm{OR}=2.8$ (2.4 to 3.3$)$ ). Hand pain had an odds ratio of 2.6 (2.3 to 3.1$)$ with hand disability. It also had a comparable odds ratio of 2.3 (2.0 to 2.6) with the overall disability index.

Aging had the highest explained variance $\left(R^{2}\right)$ in the univariate analysis with hand disability, while Parkinson's disease had the highest odds ratio (18.4). Stroke and rheumatoid arthritis also had high odds ratios but, because of the relatively low prevalence, these variables showed a lower explained variance than aging. Thyroid disease, diabetes, history of fracture, osteoarthritis in any joint, and obesity (BMI $\geqslant 30$ ) each showed less than $2 \%$ explained variance. Gout did not explain any variance in the univariate model $\left(R^{2}=0\right)$. When all determinants with a p value of $<0.2$ in the univariate analysis were considered, their combined $R^{2}$ was $25.2 \%$ for hand disability. Associations of available determinants for hand disability in the univariate and multivariate analysis (OR, 95\% CI, $\left.R^{2}\right)$ are presented in table 3.

\section{Subgroup analysis}

Data were available on radiographic hand osteoarthritis for 3906 participants. Radiographic osteoarthritis had an odds ratio of 1.4 (95\% CI, 1.1 to 1.7$)$ with hand pain and 1.4 (0.9 to
2.0) with hand disability in the multivariate model. Considering all the abovementioned determinants together with hand radiography showed that positive radiographic osteoarthritis was a poor explanation for hand pain $\left(R^{2}=0.005\right)$ or hand disability $\left(R^{2}=0.000\right)$ in this population. Associations of the available determinants for hand pain or hand disability (OR, 95\% $\mathrm{CI}, R^{2}$ ) in this subgroup are presented in tables 4 and 5. Additional analysis using the GEE technique yielded similar results to the ordinary logistic regression model.

\section{DISCUSSION}

About $16.9 \%$ of this elderly population had pain in the left or right hand during the previous month, and $13.6 \%$ had moderate to complete hand disability. The contribution of available potential determinants in this study was about $20 \%$ for hand pain and $25.2 \%$ for hand disability in an unselected population of elderly people. Thus the greater part of hand pain or hand disability remains unexplained.

People with hand pain showed a higher prevalence of joint complaints at other sites than those without hand pain. The tendency to report concurrent complaints in different joints supports the view that systemic factors play a more important role than local factors. Contrary to our expectation, age was not a determinant for hand pain. The same results were reported for pain in the hip joints in the Rotterdam study. ${ }^{31}$ Helme and Gibson found that pain increased with age only up to the seventh decade. They attributed this to a lower response rate in older people, a select sample of survivors, misattribution of the pain symptom to the aging process itself, or possible age related changes in the function of pain pathways. $^{32}$ Thus age related pain differences should probably be studied in participants with a broader age range.

As expected, rheumatoid arthritis and osteoarthritis in any joint were major determinants of hand pain in our study. However, the contribution of rheumatoid arthritis and osteoarthritis in any joints may be overestimated-first, because the diagnosis was probably based on a consultation for the dependent variable of interest (hand pain), and second, because our measurement was based on self report and participants may have misattributed another form of hand pain to rheumatoid arthritis or osteoarthritis. Compared with other studies, a relatively high percentage of our population reported having rheumatoid arthritis $(3.6 \%$ $v 0.7 \%$ to $2 \%) .{ }^{33}{ }^{34}$ However, as Picavet and Hazes confirmed

\begin{tabular}{|c|c|c|c|c|}
\hline \multirow[b]{2}{*}{ Determinant } & \multirow{2}{*}{$\begin{array}{l}\text { Frequency } \\
(\%)\end{array}$} & \multirow{2}{*}{$\begin{array}{l}R^{2} \text { in univariate } \\
\text { analysis }\end{array}$} & \multicolumn{2}{|l|}{ Odds ratio $(95 \% \mathrm{Cl})$} \\
\hline & & & Univariate analysis & Multivariate model† \\
\hline Rheumatoid arthritis & 3.6 & 0.082 & 12.4 (9.5 to 16.2$)$ & $9.5(6.9$ to 13.1$)$ \\
\hline Pain in neck/shoulder & 22.0 & 0.076 & 3.5 (3.1 to 4.0$)$ & $2.5(2.1$ to 2.8$)$ \\
\hline Osteoarthritis in any joint & 24.2 & 0.068 & $3.2(2.8$ to 3.6$)$ & 2.7 (2.3 to 3.2$)$ \\
\hline Female sex & 61.1 & 0.043 & $2.6(2.2$ to 3.0$)$ & 2.0 (1.7 to 2.4$)$ \\
\hline Thyroid disease* & 16.9 & 0.009 & $1.7(1.5$ to 2.1$)$ & $1.4(1.1$ to 1.8$)$ \\
\hline $\mathrm{BMI} \geqslant=30 \mathrm{~kg} / \mathrm{m}^{2}$ & 14.5 & 0.004 & $1.4(1.2$ to 1.7$)$ & $1.1(0.9$ to 1.3$)$ \\
\hline $\begin{array}{l}\text { History of fracture (hand/ } \\
\text { wrist) }\end{array}$ & 13.8 & 0.002 & $1.4(1.1$ to 1.7$)$ & $1.3(0.9$ to 1.8$)$ \\
\hline Diabetes & 6.7 & 0.001 & $1.3(1.0$ to 1.6$)$ & 1.1 (0.8 to 1.5$)$ \\
\hline Manual occupation & 28.3 & 0.001 & $1.1(1.0$ to 1.3$)$ & $0.9(0.7$ to 1.0$)$ \\
\hline Gout & 0.8 & 0.000 & $1.6(0.9$ to 2.9$)$ & $1.4(0.6$ to 2.9$)$ \\
\hline Stroke & 4.6 & 0.000 & $1.0(0.7$ to 1.3$)$ & - \\
\hline Age $\geqslant 70$ years & 48.2 & 0.000 & $1.0(0.9$ to 1.2$)$ & - \\
\hline Parkinson's disease & 1.0 & 0.000 & $1.1(0.6$ to 2.1$)$ & - \\
\hline \multicolumn{5}{|c|}{$\begin{array}{l}\text { Total explained variance of hand pain with all determinants in the multivariate logistic regression model was } \\
19.8 \% \text {. } \\
\text { *Thyroid disease consists of hypothyroidism, hyperthyroidism, or other thyroid disease. } \\
\text { †Determinants with } p \text { value }>0.2 \text { omitted from the multivariate logistic regression model. } \\
\text { BMI, body mass index; } \mathrm{Cl} \text {, confidence interval. }\end{array}$} \\
\hline
\end{tabular}


Table 3 Logistic univariate and multivariate analysis of the contribution of available determinants for hand disability $(n=7983)$

\begin{tabular}{|c|c|c|c|c|}
\hline \multirow[b]{2}{*}{ Determinant } & \multirow{2}{*}{$\begin{array}{l}\text { Frequency } \\
(\%)\end{array}$} & \multirow{2}{*}{$\begin{array}{l}R^{2} \text { in univariate } \\
\text { analysis }\end{array}$} & \multicolumn{2}{|l|}{ Odds ratio $(95 \% \mathrm{Cl})$} \\
\hline & & & Univariate analysis & Multivariate model† \\
\hline Age $\geqslant 70$ years & 48.2 & 0.143 & $6.4(5.4$ to 7.6$)$ & 4.5 (3.6 to 5.6$)$ \\
\hline Rheumatoid arthritis & 3.6 & 0.045 & $6.3(4.9$ to 8.1$)$ & 3.3 (2.3 to 4.7$)$ \\
\hline Stroke & 4.6 & 0.043 & $5.2(4.1$ to 6.5$)$ & 4.8 (3.4 to 6.8$)$ \\
\hline Female sex & 61.1 & 0.044 & 2.8 (2.4 to 3.3$)$ & $2.2(1.7$ to 2.8$)$ \\
\hline Hand pain & 16.8 & 0.035 & $2.6(2.3$ to 3.1$)$ & $2.4(1.9$ to 3.0$)$ \\
\hline Parkinson's disease & 1.0 & 0.033 & 18.4 (10.9 to 30.8$)$ & 23.8 (11.4 to 49.5 ) \\
\hline Pain in neck/shoulder & 22.0 & 0.026 & $2.2(1.9$ to 2.5$)$ & 1.8 (1.4 to 2.2 ) \\
\hline Manual occupation & 28.3 & 0.025 & 2.0 (1.8 to 2.3$)$ & 1.5 (1.2 to 1.8$)$ \\
\hline Thyroid disease* & 16.9 & 0.015 & 2.0 (1.7 to 2.3$)$ & $1.2(0.9$ to 1.6$)$ \\
\hline Diabetes & 6.7 & 0.014 & $2.4(2.0$ to 3.0$)$ & $1.6(1.1$ to 2.2$)$ \\
\hline $\begin{array}{l}\text { History of fracture (hand/ } \\
\text { wrist) }\end{array}$ & 13.8 & 0.008 & $1.8(1.5$ to 2.1$)$ & $0.9(0.6$ to 1.3$)$ \\
\hline Osteoarthritis in any joint & 24.2 & 0.009 & $1.6(1.4$ to 1.9$)$ & $1.1(0.9$ to 1.4$)$ \\
\hline $\mathrm{BMI} \geqslant 30 \mathrm{~kg} / \mathrm{m}^{2}$ & 14.5 & 0.001 & $1.3(1.0$ to 1.5$)$ & $0.8(0.6$ to 1.1$)$ \\
\hline Gout & 0.8 & 0.000 & $0.9(0.4$ to 2.0$)$ & - \\
\hline \multicolumn{5}{|c|}{$\begin{array}{l}\text { Total explained variance of hand disability with all determinants in the multivariate logistic regression model was } \\
25.2 \% \text {. } \\
\text { *Thyroid disease consists of hypothyroidism, hyperthyroidism, or other thyroid disease. } \\
\text { tDeterminants with p value }>0.2 \text { omitted from the multivariate model. } \\
\text { BMI, body mass index; } \mathrm{Cl} \text {, confidence interval. }\end{array}$} \\
\hline
\end{tabular}

in an earlier study, the prevalence of all self reported disease is high. ${ }^{35}$

We used $R^{2}$, the fraction of variance explained by a certain determinant, to evaluate the contribution of potential determinants to the occurrence of hand pain and hand disability in the population. For example, Parkinson's disease had an odds ratio of 18.4 with hand disability, indicating a high risk for individuals with this condition. However, it is a relatively rare disease (with a prevalence of $1 \%$ ) and therefore the fraction of the variance explained by this determinant is low (0.033). A determinant with a higher prevalence, for instance "aging", shows a higher fraction of explained variance $(0.143)$, although the relation of aging to hand disability is weaker in individuals $(\mathrm{OR}=6.4)$. Nevertheless, we presented both values (OR and $R^{2}$ ).

It complicated to take into account the contribution of side specific determinants such as shoulder pain, history of fracture (hand/wrist), and radiographic hand osteoarthritis with respect to hand pain on the same side. To do this, we used logistic regression for repeated measurement (GEE). This technique calculates the relations of each hand as the unit of analysis, but accounts for the correlation between fellow hands. However, the odds ratios computed by the GEE technique (in the total population and in the subgroup) were almost the same as when using ordinary logistic regression. Because the GEE technique does not compute the explained variance $\left(R^{2}\right)$, the tables present only the results of ordinary logistic regression analysis.

Hand pain showed nearly the same relation to hand disability and to the overall disability index; this might be explained by the fact that hand pain coexists strongly with pain in the other joints, or it might be a result of the strong relation between hand disability and the overall disability index $(r=0.83)$.

We assume that our hand disability index has sufficient validity because the questions on the HAQ related to hand function were used for construction of the hand disability index. Furthermore, the construction of this index was carried out in exactly the same way as for the overall disability index. Many validation studies of the HAQ have shown good validity, reproducibility, and sensitivity. ${ }^{25} 3637$ Limaye et al reported that the Log Sollerman D-score, which is

Table 4 Logistic univariate and multivariate analysis of the contribution of available determinants for hand pain in the subgroup $(n=3906)$

\begin{tabular}{lclll}
\hline & \multirow{2}{*}{$\begin{array}{l}\text { Frequency } \\
\text { Determinant }\end{array}$} & $\begin{array}{l}\boldsymbol{R}^{2} \text { in univariate } \\
\text { analysis }\end{array}$ & Odds ratio (95\% Cl) & \\
\cline { 5 - 6 } & & & Univariate analysis & Multivariate model \\
\hline Rheumatoid arthritis & 2.8 & 0.044 & $8.8(5.7$ to 13.9$)$ & $7.4(4.5$ to 12.1$)$ \\
Pain in neck/shoulder & 21.9 & 0.048 & $2.8(2.3$ to 3.4$)$ & $2.0(1.6$ to 2.5$)$ \\
Osteoarthritis in any joint & 24.7 & 0.077 & $3.5(2.9$ to 4.2$)$ & $3.0(2.4$ to 3.7$)$ \\
Female sex & 58.3 & 0.052 & $2.8(2.3$ to 3.5$)$ & $2.3(1.8$ to 2.9$)$ \\
Thyroid disease* & 11.5 & 0.005 & $1.6(1.2$ to 2.2$)$ & $1.1(0.8$ to 1.6$)$ \\
BMl $\geqslant 30 \mathrm{~kg} / \mathrm{m}^{2}$ & 13.8 & 0.001 & $1.2(0.9$ to 1.5$)$ & $0.8(0.6$ to 1.1$)$ \\
History of fracture (hand/wrist) & 9.3 & 0.000 & $1.2(0.8$ to 1.6$)$ & $1.0(0.6$ to 1.4$)$ \\
Diabetes & 4.7 & 0.002 & $1.5(1.0$ to 2.2$)$ & $1.3(0.8$ to 2.0$)$ \\
Manual occupation & 29.4 & 0.000 & $1.1(0.9$ to 1.3$)$ & $0.8(0.7$ to 1.1$)$ \\
Gout & 0.8 & 0.000 & $1.6(0.6$ to 3.9$)$ & $1.3(0.4$ to 3.6$)$ \\
Stroke & 2.6 & 0.000 & $1.0(0.6$ to 1.8$)$ & - \\
Age $\geqslant 70$ years & 30.8 & 0.000 & $1.0(0.8$ to 1.2$)$ & - \\
Parkinson's disease & 0.4 & 0.000 & $0.5(0.1$ to 3.6$)$ & - \\
Radiological hand OA & 28.3 & 0.016 & $1.8(1.4$ to 2.1$)$ & $1.4(1.1$ to 1.7$)$ \\
\hline
\end{tabular}

Total explained variance of hand pain with all determinants in the multivariate logistic regression model was $17.9 \%$.

*Thyroid disease consists of hypothyroidism, hyperthyroidism, or other thyroid disease.

$\mathrm{BMI}$, body mass index; $\mathrm{Cl}$, confidence interval; $\mathrm{OA}$, osteoarthritis. 
a performance based test assessing unilateral and bilateral hand grip function in activities of daily living, accurately reflects patient function as measured by the HAQ. ${ }^{38}$

Finally, this study has a number of potential limitations. First, the Rotterdam study was primarily designed as a study of determinants and prognosis of chronic diseases in the elderly, and not specifically for hand disease. Thus we do not have information on all determinants of interest, such as carpal tunnel syndrome and other specific wrist/hand diseases or psychosocial factors. Second, there was some selection in the subgroup used for the analysis of radiographic hand osteoarthritis. Radiographic data were only available for the 3906 participants who were accessible for follow up six years later. The total population available at baseline $(n=7983)$ was older, much more disabled, and contained more women than the subgroup with data on radiographic hand osteoarthritis $(n=3906)$. Prevalence of hand pain was the same, but the prevalence of hand disability was much lower in the subgroup. Although the total explained variance in the whole population and in the subgroup were comparable, the odds ratio of the determinants differed slightly for the hand pain and more definitely for the hand disability. This is probably because of a marked difference in the prevalence of hand disability in the overall population compared with the subgroup. Also the prevalence of some determinants differed from that in the total population. Thus the additional explained variance of radiographic hand osteoarthritis may be underestimated. Third, our participants were over 55 years of age and therefore most of them were retired and their most recent job was included in the analysis. An active working population would probably show a stronger association of manual occupations with hand pain or disability.

Despite these limitations, to our knowledge this is the first study to give some insight into hand pain and disability and the interrelations of their potential determinants in an elderly population. Our study shows that about $20 \%$ of hand pain and about $25 \%$ of hand disability can be explained by potential determinants available in our population. It also shows that determining the presence of radiographic osteoarthritis contributes very little to the total explained variance of hand pain and hand disability. Thus the greater part of the variance of hand pain or disability remains unexplained. Further investigations should aim to identify other important determinants (both local and systemic) of hand pain and disability in the elderly. Psychological factors should also be considered in future studies.

\section{ACKNOWLEDGEMENTS}

We are grateful to the participants and staff of the Rotterdam study. We thank Mrs R Bernsen for statistical analysis and Dr A Ginai and Mr U Cimen for scoring the radiographs.

\section{Authors' affiliations}

S Dahaghin, S M A Bierma-Zeinstra, M Reijman, B W Koes, Department of General Practice, Erasmus Medical Centre, Rotterdam, Netherlands

H A P Pols, J M W Hazes, Department of Epidemiology and Biostatistics, Erasmus Medical Centre

\section{APPENDIX 1}

Questions on the health assessment questionnaire (HAQ) used for the hand disability index.

Are you able to?

1. Dress yourself, including managing fasteners?

2. Comb your hair and do your own makeup?

3. Turn taps on and off?

4. Cut your meat, and lift a full cup or glass to your mouth?
5. Open a new milk carton?

6. Open car doors?

7. Hold a pen or a pencil?

8. Open jars which have been previously opened?

\section{APPENDIX 2}

Definition of the Kellgren-Lawrence radiographic grades

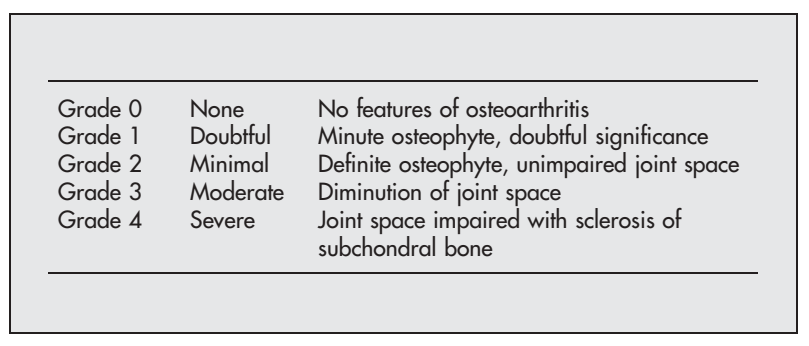

\section{REFERENCES}

1 Elliott AM, Smith BH, Penny KI, Smith WC, Chambers WA. The epidemiology of chronic pain in the community. Lancet 1999;9:1248-52.

2 Wilder-Smith $\mathrm{OH}$, Mohrle JJ, Dolin PJ, Martin NC. The management of chronic pain in Switzerland: a comparative survey of Swiss medical specialists treating chronic pain. Eur J Pain 2001;5:285-98.

3 Palmer KT. Regional musculoskeletal conditions: pain in the forearm, wrist and hand. Best Pract Res Clin Rheumatol 2003;17:113-35.

4 Palmer KT, Syddall H, Cooper C, Coggon D. Smoking and musculoskeletal disorders: findings from a British national survey. Ann Rheum Dis 2003;62:33-6

5 Urwin M, Symmons D, Allison T, Brammah T, Busby $H$, Roxby $M$, et al. Estimating the burden of musculoskeletal disorders in the community: the comparative prevalence of symptoms at different anatomical sites, and the relation to social deprivation. Ann Rheum Dis 1998;57:649-55.

6 Eberhardt KB, Fex E. Functional impairment and disability in early rheumatoid arthritis - development over 5 years. J Rheumatol 1995:22:1037-42.

7 Dellhag B, Bjelle A. A five-year followup of hand function and activities of daily living in rheumatoid arthritis patients. Arthritis Care Res 1999; 12:33-41.

8 Dellhag B, Hosseini N, Bremell T, Ingvarsson PE. Disturbed grip function in women with rheumatoid arthritis. J Rheumatol 2001;28:2624-33.

9 Zyluk A, Zyluk B. [Shoulder-hand syndrome in patients after stroke]. Neurol Neurochir Pol 1999;33:131-42.

10 Allander E. Epidemiology of the rheumatic diseases. Curr Opin Rheumatol 1994;6:122-31.

11 Qiao Q, Keinanen-Kiukaanniemi S, Rajala U, Uusimaki A, Kivela SL. Rheumatic pains of previously undiagnosed diabetic subjects. Scand J Rheumatol 1995;24:234-7.

12 Carmeli E, Patish H, Coleman R. The aging hand. J Gerontol A Biol Sci Med Sci 2003;58:146-52.

13 Viegas SF. Atypical causes of hand pain. Am Fam Physician 1987;35:167-72.

14 Moore JR, Weiland AJ. Gouty tenosynovitis in the hand. J Hand Surg Am 1985;10:291-5.

15 Acheson RM. Heberden Oration 1981: epidemiology and the arthritides. Ann Rheum Dis 1982;41:325-34

16 Fredriksson $\mathrm{K}$, Alfredsson $\mathrm{L}$, Koster $\mathrm{M}$, Thorbjornsson CB, Toomingas $\mathrm{A}$, Torgen $M$, et al. Risk factors for neck and upper limb disorders: results from 24 years of follow up. Occup Environ Med 1999;56:59-66.

17 Karpitskaya Y, Novak CB, Mackinnon SE. Prevalence of smoking, obesity, diabetes mellitus, and thyroid disease in patients with carpal tunnel syndrome. Ann Plast Surg 2002;48:269-73.

18 Dillon C, Petersen M, Tanaka S. Self-reported hand and wrist arthritis and occupation: data from the U.S. National Health Interview SurveyOccupational Health Supplement. Am J Indust Med 2002;42:318-27.

19 Kalb RL. Evaluation and treatment of wrist and hand pain. Hosp Pract 1998:33:129-32.

20 Makabe H, Sakamoto K. Judgment of disability stages in Parkinson disease patients due to pathological tremor of index finger. Electromyogr Clin Neurophysiol 2000;40:397-409.

21 Harris TB. Invited commentary: body composition in studies of aging: new opportunities to better understand health risks associated with weight. Am J Epidemiol 2002;156:122-4.

22 Hofman A, Grobbee DE, de Jong PT, van den Ouweland FA. Determinants of disease and disability in the elderly: the Rotterdam Elderly Study. Eur J Epidemiol 1991;7:403-22.

23 Fries JF, Spitz PW, Young DY. The dimensions of health outcomes: the health assessment questionnaire, disability and pain scales. J Rheumatol 1982;9:789-93. 
24 Bruce B, Fries JF. The Stanford Health Assessment Questionnaire: dimensions and practical applications. Health Qual Life Outcomes 2003;1:20.

25 Siegert CE, Vleming $U$, Vandenbroucke JP, Cats A. Measurement of disability in Dutch rheumatoid arthritis patients. Clin Rheumatol 1984;3:305-9.

26 Beroepenclassificatie 1984. List voor benamingen per beroepencode/Central bureau voor de statistiek. ISBN 90-6786-040-9.

27 Kallman DA, Wigley FM, Scott WW, Hochberg MC, Tobin JD. New radiographic grading scales for osteoarthritis of the hand. Reliability for determining prevalence and progression. Arthritis Rheum 1989;32:1584-91.

28 Hirsch R, Lethbridge-Cejku M, Hanson R, Scott WW, Reichle R, Plato CC, et al. Familial aggregation of osteoarthritis: data from the Baltimore Longitudinal Study on Aging. Arthritis Rheum 1998;41:1227-32.

29 Hirsch R, Lethbridge-Cejku M, Scott WW, Reichle R, Plato CC, Tobin J, et al. Association of hand and knee osteoarthritis: evidence for a polyarticular disease subset. Ann Rheum Dis 1996;55:25-9.

30 Diggle PJ, Liang KY, Zeger SL. Analysis of longitudinal data. Oxford: Clarendon press, 1994.

31 Odding E, Valkenburg HA, Algra D, Vandenouweland FA, Grobbee DE, Hofman A. Associations of radiological osteoarthritis of the hip and knee with locomotor disability in the Rotterdam Study. Ann Rheum Dis 1998;57:203-8.
32 Helme RD, Gibson SJ. The epidemiology of pain in elderly people. Clin Geriatr Med 2001;17:417-31.

33 Lawrence RC, Helmick CG, Arnett FC, Deyo RA, Felson DT, Giannini EH, et al. Estimates of the prevalence of arthritis and selected musculoskeletal disorders in the United States. Arthritis Rheum 1998:41:778-99.

34 Rasch EK, Hirsch R, Paulose-Ram R, Hochberg MC. Prevalence of rheumatoid arthritis in persons 60 years of age and older in the United States: effect of different methods of case classification. Arthritis Rheum 2003:48:917-26

35 Picavet HS, Hazes JM. Prevalence of self reported musculoskeletal diseases is high. Ann Rheum Dis 2003;62:644-50.

36 Liang MH, Larson MG, Cullen KE, Schwartz JA. Comparative measurement efficiency and sensitivity of five health status instruments for arthritis research. Arthritis Rheum 1985;28:542-7.

37 Van Der Heijde DM, van Riel PL, van de Putte LB. Sensitivity of a Dutch Health Assessment Questionnaire in a trial comparing hydroxychloroquine vs. sulphasalazine. Scand J Rheumatol 1990;19:407-12.

38 Limaye V, Frankham A, Disney A, Pile K. Evaluation of hand function in patients undergoing long term haemodialysis. Ann Rheum Dis $2001 ; 60: 278-80$ 


\section{PostScript}

\section{MATTERS ARISING}

\section{Is IV infliximab better than IV methylprednisolone for the treatment of patients with RA when methotrexate fails?}

A recent paper described a randomised comparative study of intravenous (IV) pulse methylprednisolone versus infliximab treatment in patients for whom methotrexate treatment had failed. ${ }^{1}$ The conclusions that infliximab treatment offered substantial benefits over IV methylprednisolone may be correct, but the design of the trial has resulted in a biased assessment in favour of IV infliximab treatment. In addition, the failure of the IV methylprednisolone treatment to alter significantly a number of clinical and laboratory measures, including serum C reactive protein levels, is at odds with published reports. ${ }^{2-7}$

A comparison between the patient group in that study ${ }^{1}$ and our previous papers on the use of IV methylprednisolone treatment ${ }^{236}$ suggests that the patients in each study had similar disease duration, seropositivity, and clinical and laboratory measures of disease activity. Two main differences between the two patient groups are the background corticosteroid use (none in our study and most patients in the study by Durez et al) and the use of methotrexate. It has been our anecdotal experience that patients receiving long term oral corticosteroids do not respond as well, or for as long, to IV methylprednisolone as do patients who are not receiving oral corticosteroids and may require more frequent administrations of IV methylprednisolone for the same effect. However, I am not aware of any published data to support this. Whether this might explain the lack of response to IV methylprednisolone in the study by Durez et al is unclear.

In addition, the comparison between a single dose of IV methylprednisolone and three infliximab infusions, while reflecting the authors' usual clinical practice, is certainly a comparison biased in favour of the infliximab treated patient group. It should be remembered that there are no published data to validate the requirement for infliximab infusions at 0,2 , and 6 weeks. Some evidence suggests that a more sustained response to daily infusions of $1000 \mathrm{mg}$ methylprednisolone succinate for 3 days rather than a single IV infusion is preferable, and our own studies showed a mean duration of response of only 5.1 weeks, suggesting that repeated infusions with IV methylprednisolone might have resulted in more benefit from this treatment. It might have been better for the authors to compare either consecutive daily infusions for 3 days or monthly infusions of IV methylprednisolone, especially as the main outcome measures were at week 14 after treatment.

M D Smith

Rheumatology Unit, Repatriation General Hospital, Adelaide, South Australia

\section{Rapid response}

If you have a burning desire to respond to a paper published in the Annals of the Rheumatic Diseases, why not make use of our "rapid response" option?

Log on to our website (www. annrheumdis.com), find the paper that interests you, and send your response via email by clicking on the "eLetters" option in the box at the top right hand corner.

Providing it isn't libellous or obscene, it will be posted within seven days. You can retrieve it by clicking on "read eletters" on our homepage.

The editor will decide as before whether also to publish it in a future paper issue.

Correspondence to: Dr M D Smith; malcolm.smith@ rgh.sa.gov.au

\section{References}

1 Durez P, Toukap AN, Lauwerys BR, Manicourt DH Verschueren $\mathrm{P}$, Westhovens $\mathrm{R}$, et al. A randomised comparative study of the short term clinical and biological effects of intravenous pulse methylprednisolone and infliximab in patients with active rheumatoid arthritis despite methotrexate treatment. Ann Rheum Dis 2004;63: 1069-74

2 Smith MD, Bertouch JV, Smith AM, Weatherall M, Ahern MJ, Brooks PM, et al. The clinical and immunological effects of pulse methylprednisolone therapy in rheumatoid arthritis. I. Clinical effects. J Rheumato 1988; 15:229-32.

3 Smith MD, Ahern MJ, Brooks PM, RobertsThomson PJ. The clinical and immunological effects of pulse methylprednisolone therapy in rheumatoid arthritis. II. Effects on immune and inflammatory indices in peripheral blood. $J$ Rheumatol 1988;15:233-7.

4 Williams JA, Baylis EM, Shipley ME. A double blind placebo controlled trial of methylprednisolone pulse therapy in active rheumatoid disease. Lancet 1982;2:237-40.

5 Liebling MR. Pulse methylprednisolone therapy in active rheumatoid arthritis. Internal Medicine for the Specialist 1983;4:8.

6 Youssef PP, Cormack J, Evill CA, Peter DT, Roberts-Thomson PJ, Ahern MJ, Smith MD. Neutrophil trafficking into inflamed joints in patients with rheumatoid arthritis and the effects of methylprednisolone. Arthritis Rheum 1996;39:216-25.

7 Barry M. The use of high-dose pulse methylprednisolone in rheumatoid arthritis. Arch Intern Med 1985; 145: 1483-4.

\section{Authors' reply}

We thank Dr Smith for his comments on our study, ${ }^{1}$ which were largely addressed by Buttgereit et al. ${ }^{2}$ As already answered, the lack of significant response to intravenous methylprednisolone in our group of patients with rheumatoid arthritis (RA) is probably related to their disease severity, reflected by their previous treatments.

As an alternative hypothesis, suggested by Dr Smith, we can also speculate that our patients belong to a corticosteroid resistant RA subset. The mechanisms of resistance to steroids are unknown in RA but have recently been explored in patients with asthma. ${ }^{3}$
P Durez, T A Nzeusseu, B R Lauwerys, D H Manicourt, J-P Devogelaer, F A Houssiau Rheumatology Department, Cliniques Universitaires Saint-Luc (Université catholique de Louvain), Belgium

P Verschueren, R Westhovens UZ Gasthuisberg (Katholieke Universiteit Leuven), Belgium

Correspondence to: Dr F A Houssiau, Rheumatology Department, Cliniques Univeritaires Saint-Luc, Université catholique de Louvain, Avenue Hippocrate 10, B-1200 Brussels, Belgium; houssiau@ ruma.ucl.ac.be

\section{References}

1 Durez P, Nzeusseu Toukap A, Lauwerys BR Manicourt DH, Verschueren $P$, Westhovens $R$, et al. A randomised comparative study of the short term clinical and biological effects of intravenous pulse methylprednisolone and infliximab in patients with active rheumatoid arthritis despite methotrexate treatment. Ann Rheum Dis 2004;63:1069-74.

2 Buttgereit F, Burmester G, Bijlsma JW. Which dose regimen for glucocorticoid pulse therapy in patients with severe refractory RA? Ann Rheum Dis 2005;64:171-2.

3 Matthews JG, Ito K, Bames PJ, Adcock IM. Defective glucocorticoid receptor nuclear translocation and altered histone acetylation patterns in glucocorticoid-resistant patients. J Allergy Clin Immunol 2004; 1 13:1100-8.

\section{Antimicrobial treatment for Chlamydia induced reactive arthritis}

We read with interest the article entitled "Three month treatment of reactive arthritis with azithromycin: a EULAR double blind, placebo controlled study". ${ }^{1}$ The trial of Kvien et al suggests that weekly administration of azithromycin for 3 months is not efficacious in ameliorating the symptoms of reactive arthritis (ReA). Although this point seems clear, the authors then make a leap of faith and suggest that "this study does not support the prolonged use of antibiotics for the alleviation of ReA". There are several problems with this generalisation.

As Kvien et al correctly point out, polymerase chain reaction technology has documented the presence of Chlamydia and other causative organisms in the synovial tissue of patients with ReA. ${ }^{2}$ This same technology has convincingly shown both in vitro and in vivo evidence of persistent metabolically active Chlamydia. ${ }^{2}$ The data on post-dysentery organisms have repeatedly demonstrated bacterial fragments, ${ }^{3}$ but viability has only been suggested in the case of Yersinia. ${ }^{4}$ This makes a strong argument for the use of antimicrobial agents in post-chlamydial ReA, yet both patients with post-venereal and post-dysentery ReA were included in this trial.

Previous therapeutic trials also suggest that post-chlamydial ReA is more susceptible to antimicrobial treatment than the postdysentery form. A 1991 trial suggested that lymecycline was an effective treatment for post-chlamydial ReA, but not for the postdysentery form. ${ }^{5}$ A subgroup analysis of postchlamydial patients in another trial assessing 
ciprofloxacin showed a trend towards improvement. ${ }^{6}$ There were not enough postchlamydial patients in the trial of Kvien et al for a meaningful analysis to be made.

We also question the treatment itself in their trial. A one-time dose of $1000 \mathrm{mg}$ of azithromycin is approved for an acute Chlamydia infection; however, the proper dose for persistent infection has not been established. To our knowledge, $1000 \mathrm{mg}$ weekly has never even been studied in vitro as a dose to treat persistent Chlamydia. In addition, persistent Chlamydia infections intermittently shed infectious elementary bodies, potentially evading weekly pulse antimicrobial treatment. It has also been demonstrated that the chronic treatment of Chlamydia trachomatis with azithromycin in vitro caused the Chlamydia temporarily to arrest in a persistent viable state. ${ }^{7}$ Lastly, it has not been established if 3 months of a single antimicrobial agent is successful at treating an obligate intracellular organism that exists in the form of a reticulate body. Other obligate intracellular organisms, such as Mycobacterium tuberculosis, require 9 months of combination antimicrobial treatment to ensure therapeutic response.

Kvien et al implied that their trial, along with previous trials, indicates a lack of efficacy of antibiotics in ReA. The antibiotics studied previously included tetracyclines, ciprofloxacin, and now azithromycin. ${ }^{156}$ Chlamydia has demonstrated in vitro resistance to all of these antibiotics upon chronic administration. ${ }^{78}$ Further, ciprofloxacin has been shown to cause tendon based inflammation by potentiating interleukin $1 \beta$ stimulated metalloproteinase- 3 output in tendons. ${ }^{9}$ Is this then the proper antibiotic to choose in the treatment of an enthesophyte based inflammatory arthritis?

We have recently completed a trial assessing a 9 month course of a combination of doxycycline and rifampin versus doxycycline monotherapy. ${ }^{10}$ The results showed a rather dramatic response in the patients who received the combination. The chlamydial resistance that has been documented in vitro, was overcome when a combination of antibiotics were used. ${ }^{7}$ Ours was the first trial to assess a combination of antibiotics in this setting.

Do antibiotics work in ReA, specifically Chlamydia induced ReA? In our opinion, this question has not been answered. We believe studies of large groups of patients, with the appropriate antibiotics, in the right dose, used for the proper length of time, need to be conducted before this question can be answered.

J D Carter, J Valeriano, F B Vasey University of South Florida, Division of Rheumatology, 12901 Bruce B Downs Blvd, MDC 81 Tampa FL 33612, USA

Correspondence to: Dr J D Carter; jocarter@hsc.usf.edu

\section{References}

1 Kvien TK, Gaston JSH, Bardin T, Butrimiene I, Dijkmans BAC, Leirisalo-Repo $M$, et al. Three month treatment of reactive arthritis with azithromycin: a EULAR double blind, placebo controlled study. Ann Rheum Dis 2004:63:1113-19.

2 Gerard HC, Branigan PJ, Schumacher HR Jr, Hudson AP. Synovial chlamydia trachomatis in patients with reactive arthritis/Reiter's syndrome are viable but show aberrant gene expression. J Rheumatol 1998;25:734-42.

3 Granfors K, Jalkanen S, Lindberg AA, MakiIkola $O$, von Essen $R$, Lahesmaa-Rantala $R$, et al. Salmonella lipopolysaccharide in synovial cells from patients with reactive arthritis. Lancet 1990;335:685-8.

4 Gaston JS, Cox C, Granfors K. Clinical and experimental evidence for persistent Yersinia infection in reactive arthritis. Arthritis Rheum 1999;42:2239-42.

5 Lauhio A, Leirisalo-Repo M, Lahdevirta J, Saikku P, Repo H. Double-blind, placebocontrolled study of three-month treatment with lymecycline in reactive arthritis, with special reference to Chlamydia arthritis. Arthritis Rheum 1991;34:6-14.

6 Sieper J, Fendler C, Laitko S, Sorensen H, Gripenberg-Lerche C, Hiepe F, et al. No benefit of long-term ciprofloxacin in patients with reactive arthritis and undifferentiated oligoarthritis: a three-month, multicenter, double-blind, randomized, placebo-controlled study. Arthritis Rheum 1999;42:1386-96.

7 Dreses-Werringloer U, Padubrin I, Zeidler $\mathrm{H}$, Kohler L. Effects of azithromycin and rifampin on Chlamydia trachomatis infection in vitro. Antimicrob Agents Chemother 2001;45:3001-8.

8 Dreses-Werringloer U, Padubrin I, JurgensSaathoff B, Hudson AP, Zeidler H, Kohler L. Persistence of Chlamydia trachomatis is induced by ciprofloxacin and ofloxacin in vitro. Antimicrob Agents Chemother 2000;44:3288-97

9 Corps AN, Harrall RL, Curry VA, Fenwick SA, Hazleman BL, Riley GP. Ciprofloxacin enhances the stimulation of matrix metalloproteinase 3 expression by interleukin-1 beta in human tendonderived cells. A potential mechanism for fluoroquinolone-induced tedinopathy. Arthritis Rheum 2002;46:3034-40.

10 Carter JD, Valeriano J, Vasey FB. Doxycycline vs. doxycycline and rifampin in undifferentiated spondyloarthropathy - with special reference to Chlamydia-induced arthritis. A prospective, randomized 9-month comparison. J Rheumatol 2004;31:1973-80.

\section{Authors' reply}

We thank Carter et $a l^{1}$ for their valuable comments on our paper which reported the results of 3 months' treatment of reactive arthritis (ReA) with azithromycin. ${ }^{2}$ The data from our study definitely did not support prolonged use of antibiotics for the alleviation of ReA, because no trend was found in favour of long term treatment. However, we do not disagree that the data from the study by Carter et al, ${ }^{1}$ and from other authors, ${ }^{3}$ may support long term treatment with antibiotics in patients with ReA induced by Chlamydia trachomatis.

Such positive findings as have been reported seem to be restricted to this microbiological agent. We note that the study by Carter et al ${ }^{1}$ was performed in patients with chronic undifferentiated spondyloarthropathy without confirmed Chlamydia infection, but 9 of 30 patients had either a possible or probable preceding symptomatic Chlamydia infection.

We also agree that various arguments can be employed in the selection of the optimal antimicrobial agent in ReA. We chose azithromycin in our study because of its acceptable tolerability profile combined with a broad antimicrobial spectrum, as our study was designed to focus on all patients in whom ReA was a likely diagnosis-not just patients with Chlamydia induced ReA. Carter et al compared doxycycline $100 \mathrm{mg}$ twice a day with doxycycline $100 \mathrm{mg}$ twice a day + rifampicin $600 \mathrm{mg}$ a day. ${ }^{1}$ The latter drug is most widely used for the treatment of tuberculosis. The safety of this combination should be clarified before recommendations are given for its wider use in ReA or undifferentiated spondyloarthritis.

We would also welcome an adequately powered trial confined to patients with Chlamydia induced arthritis, to clarify the efficacy or otherwise of long term treatment with antibiotics in this condition. However, in our opinion, such a trial will be difficult to perform, because of the logistic problems of recruiting large numbers of bacteriologically proven cases early in the course of their disease. For the present, therefore, clinicians must base their treatment on currently available data.

J S H Gaston

Department of Rheumatology, Addenbrooke's Hospital, Box 157, Level 5, Hills Road, Cambridge

CB2 2QQ, UK

T K Kvien

Department of Rheumatology, Diakonhiemmet Hospital, Oslo, Norway

Correspondence to: Professor J S H Gaston; jshg2@medschl.cam.ac.uk

\section{References}

1 Carter JD, Valeriano J, Vasey FB. Doxycycline versus doxycycline and rifampin in undifferentiated spondyloarthropathy, with special reference to chlamydia-induced arthritis. A prospective, randomized 9-month comparison. $J$ Rheumatol 2004;31:1973-80.

2 Kvien TK, Gaston JS, Bardin T, Butrimiene I, Dijkmans BA, Leirisalo-Repo $M$, et al. Three month treatment of reactive arthritis with azithromycin: a EULAR double blind, placebo controlled study. Ann Rheum Dis 2004;63:1113-19.

3 Lauhio A, Leirisalo-Repo M, Lahdevirta J, Saikku P, Repo H. Double-blind, placebo controlled study of three-month treatment with lymecycline in reactive arthritis, with special reference to Chlamydia arthritis. Arthritis Rheum $1991 ; 34: 6-14$

\section{Is Behçet's syndrome associated with infection?}

I read with interest that the pustular skin lesions in Behçet's syndrome (BS) had been thought aseptic, were found to be not sterile, and that the microbiology of these lesions is different from ordinary acne. ${ }^{1}$ I would like to report my observation of a patient with refractory pustulosis of Behçet's disease, who fulfilled the international study group criteria, was HLA-Bw51 positive, and had a family history of BS. The patient's skin rash disappeared after a 6 week course of cotrimoxazole (sulfamethoxazole-trimetoprim).

The patient, a 31 year old man had had recurrent oral and genital ulcers since childhood. Inflammatory joint disease developed 4 years ago, affecting shoulders, ankles, and knees, relapsing every 2-3 months. Recurrent knee effusions caused serious knee dysfunction. Skin pustulosis, which was episodic at onset, became persistent and massive during the past 4 years, affecting the body, back, and limbs (fig 1A). A skin vesicle was observed 24-48 hours after taking blood for analysis from the knee at the point of needle entry. Polyarthritis and skin pustulosis became refractory to local, systemic, and intra-articular corticosteroids and colchicine. The pustular lesions thought to be sterile in BS were not cultured. Salazopyrin, methotrexate given orally and parenterally at maximal dose of $25 \mathrm{mg} /$ week, and azathioprine failed to control the knee effusions, 

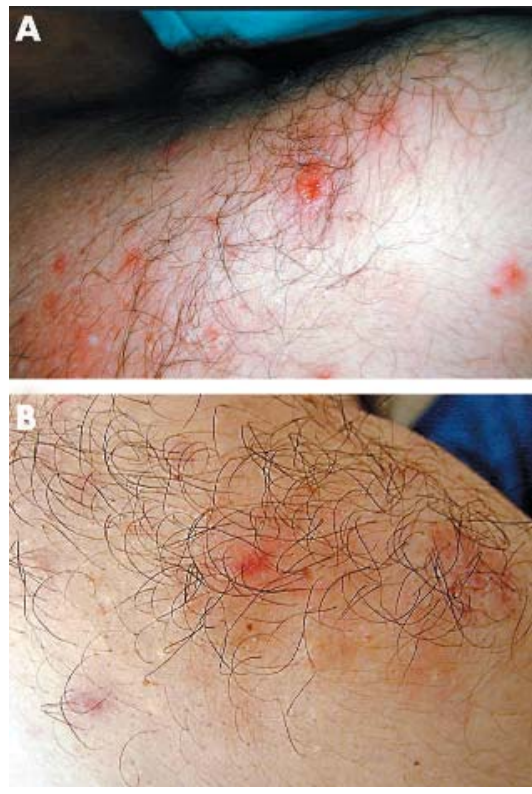

Figure 1 Pustulosis of Behçet's disease localised in the right suprascapular area: $(A)$ before co-trimoxazole treatment; (B) on the 10th day of co-trimoxazole treatment $1960 \mathrm{mg}$ twice a day).

shoulder and ankle arthritis, skin rash, and oral ulcers. Invasive knee procedures were planned.

At this point the failed second line treatment was stopped, and we made the decision to start co-trimoxazole treatment. The rationale for this was the anti-inflammatory properties of the drug reported previously $y^{2}$ and its effectiveness for some patients with Wegener's granulomatosis ${ }^{3}$ associated with severe neutrophillic activation, ${ }^{4}$ which is also seen in skin lesions of patients with BS. ${ }^{5}$

BS was reported to be associated with a higher incidence of Streptococcus mediated tonsillitis, and its adjuvant action to autoimmune disease cannot be excluded. ${ }^{6}$ Circulating immune complexes are thought to precipitate a neutrophilic vascular reaction, resulting in mucocutaneous lesions. ${ }^{78} \mathrm{~A}$ decrease in serum IgG and IgM was noted during co-trimoxazole treatment. ${ }^{2}$

Co-trimoxazole treatment was started with a daily dose of $50 \mathrm{mg} / \mathrm{kg}$ given in four divided doses $(960 \mathrm{mg} \times 4 /$ day $)$ for the first 3 days. Then the dose was reduced to $960 \mathrm{mg} \times 3$ /day given for 1 week, followed by two double strength tablets a day until 6 weeks of treatment. The pustular rash gradually disappeared (figs 1A and B). After 6 weeks of the co-trimoxazole treatment the drug was stopped and weekly methotrexate injections were restarted at the previous dose. Knee effusion has relapsed only once during 1 year of follow up.

Evidence, that infection is the most probable environmental trigger of inflammatory joint disease is controversial, but interest in the topic is growing. The relationship between infection and collagen disease may be more subtle and complex than one of simply responding to Koch's postulates.' Multiple infectious triggers which attack at an unknown rate, the delayed interval between infection and disease onset, and a role for primary, secondary, and persistent infection in the perpetuation of collagen disease are the substance of the microbiology of rheumatic diseases. Bacteria are not only a source of exogenous antigens, which potentially cross react with those of the host, but can also exert adjuvant effects and release self antigens. Lipopolysaccharides, peptidoglycans, and bacterial DNA activate the innate immune system through specialised pattern recognition receptors of the Toll-like receptor family. ${ }^{10}$ Such microbial determinants are referred to as "pathogen associated molecular patterns". These patterns, together with the self antigens, activate the production of polyreactive antibodies, cytokine, and chemokines. Infected pustules of Behçet's disease might cause severe activation of the autoimmune response. Co-trimoxazole may be a promising treatment for controlling the microbial inductors and autoimmune reactions.

\section{A P Rozin}

B Shine Department of Rheumatology, Rambam Medical Centre and B Rappaport Faculty of Medicine, Israel-Technion Institute of Technology, Haifa, Israel

Correspondence to: $\operatorname{Dr} A$ Rozin, Department of Rheumatology, Rambam Medical Center, PO Box 9602, Haifa 31096, Israel; a_rozin@ rambam.health.gov.il

\section{References}

1 Hatemi G, Bahar H, Uysal S, Mat C, Gogus F, Masatlioglu $S$, et al. The pustular skin lesions in Behcet's syndrome are not sterile. Ann Rheum Dis 2004:63:1450-2.

2 Rozin AP, Schapira D, Bergman R. Alopecia areata and relapsing polychondritis or mosaic autoimmunity. The first experience of cotrimoxazole treatment. Ann Rheum Dis 2003;62:778-80

3 DeRemee RA, McDonald TJ, Weiland LH. Wegener's granulomatosis: observations on treatment with antimicrobial agents. Mayo Clin Proc 1985;60:27-32.

4 Brouwer E, Huitema MG, Mulder AHL, Heeringa P, van Goor H, Tervaert JWC, et al. Neutrophil activation in vitro and in vivo in Wegener's granulomatosis. Kidney Int 1994;45:1120-31.

5 Ackerman AB. Behçet's disease. In: Ackerman AB, Chongchitnant N, Sanchez J, et al. Histologic diagnosis of inflammatory skin diseases. In: An algorithmic method based on pattern analysis. 2nd ed. Baltimore: Williams \& Wilkins, 1997:229-32.

6 Aoki K, Ohno S. Studies on the constitution and past history of patients with Behçet's disease. Act Soc Ophthalmol Jpn 1972;76:1608-12.

7 Williams BD, Lehner T. Immune complexes in Behçet's syndrome and recurrent oral ulcerations. BMJ 1977:1:1387-9.

8 Barton-Kee JE, Mowbray JF, Lehner T. Different cross-reacting circulating immune complexes in Behçet's disease and recurrent oral ulcers. J Lab Clin Med 1981;97:559-67.

9 Carty SM, Snowden N, Silman AJ. Should infection still be considered as the most likely triggering factor for rheumatoid arthritis? I Rheumatol 2003:30:425-9.

10 Klinman D. Does activation of the innate immune system contribute to the development of rheumatoid arthritis? Arthritis Rheum 2003:48:590-3.

\section{Authors' reply}

We thank Dr Rozin for his interest in our article and sharing his experience about a patient with Behçet's syndrome (BS) who improved with co-trimoxazole. We also recently had a patient with BS who had severe pustulosis, arthritis, oral and genital ulcers and who similarly did well with antibiotics. Staphylococcus aureus grew from both the dermal pustules and the pustular pathergy lesions.

Thus far there have been few formal studies of antibiotic use in BS. Çalgüneri $e t$ al reported that penicillin treatment was beneficial for the mucocutaneous lesions ${ }^{1}$ and arthritis. ${ }^{2}$ A similar beneficial effect was observed with minocycline, which reduced both the frequency of clinical symptoms and the production of inflammatory cytokines by peripheral blood mononuclear cells stimulated by streptococcal antigens. ${ }^{3}$

The issue of an infectious aetiology in BS has also long been discussed. Behçet himself proposed a viral aetiology. ${ }^{4}$ It has been suggested that viruses, such as herpes simplex virus ${ }^{5}$ and parvovirus, ${ }^{6}$ and bacteria including various streptococcal strains ${ }^{7}$ and staphylococci ${ }^{8}$ have a role.

In one study peripheral $\gamma \delta+C D 8+T$ cells of patients with BS showed a significantly proliferative response to the Streptococcus sanguis strain KTH-1. ${ }^{7}$ In another, T cells from patients with BS produced interferon $\gamma$ when stimulated with staphylococcal superantigens. $^{8}$ Clinical evidence for the role played by an infectious agent in pathogenesis includes the presence of a higher incidence of chronic tonsillitis and dental caries in patients with BS, ${ }^{9}$ observation of exacerbations of BS symptoms after acute episodes of infection with Streptococcus agalactiae vaginitis, ${ }^{10}$ and gingival infections with methicillin resistant Staphylococcus aureus. ${ }^{11}$

There are also reports from our group showing the association of papulopustular lesions with arthritis in BS, suggesting a reactive type of arthritis. ${ }^{12}{ }^{13}$ Lehner and colleagues suggested that a common antigen such as a stress protein might be involved.${ }^{14} \mathrm{~A}$ significant increase of IgA antibodies to mycobacterial $65 \mathrm{kDa}$ heat shock protein (HSP) in the serum of patients with BS was shown. Owing to the significant homology between mammalian and microbial HSPs, it is suggested that recurrent exposure to HSP may cause bacterial HSP responsive T cells to stimulate autoreactive $\mathrm{T}$ cells by cross reactivity mechanisms. In turn, these $\mathrm{T}$ cells might produce Thl-like proinflammatory and/or inflammatory cytokines, leading to tissue injury.

Whatever the precise pathogenic pathways will turn out to be, it is clear that further controlled trials with antibiotics in BS are warranted.

G Hatemi, H Yazici Division of Rheumatology, Department of Medicine, Cerrahpasa Medical Faculty, University of Istanbul, Aksaray 34303, Ystanbul, Turkey

Correspondence to: Dr H Yazici; hyazici@ attglobal.net

\section{References}

1 Çalgüneri M, Ertenli I, Kiraz S, Erman B, Çelik I. Effect of prophylactic benzathine penicillin on mucocutaneous symptoms of Behçet's disease. Dermatology 1996;192:125-8.

2 Çalgüneri M, Kiraz S, Ertenli I, Benekli M, Karaaslan Y, Celik I. The effect of prophylactic penicillin treatment on the course of arthritis episodes in patients with Behçet's disease. A randomized clinical trial. Arthritis Rheum 1996;39:2062-5.

3 Kaneko F, Oyama N, Nishibu A. Streptococcal infection in the pathogenesis of Behçet's disease and clinical effects of minocycline on the disease symptoms. Yonsei Med J 1997;38:444-54.

4 Behçet H. Über Rezidivierende, aphtose durch ein Virus verursachte Geschwüre am Mund, am Auge 
und an den Genitalien. Dermatol. Wochenschr 1937; 105: 1151-7.

5 Eglin RP, Lehner T, Subak-Sharpe JH. Detection of RNA complementary to herpes-simplex virus in mononuclear cells from patients with Behçet's syndrome and recurrent oral ulcers. Lancet 1982;ii:1356-61

6 Kiraz S, Ertenli I, Benekli M, Calgüneri $M$. Parvovirus B19 infection in Behçet's disease. Clin Exp Rheumatol 1996;14:71-3.

7 Mochizuki N, Suzuki N, Takeno M, Nagafuchi H Harada T, Kaneoka $\mathrm{H}$. Fine antigen specificity of human gamma delta $T$ cell lines (V gamma 9+) established by repetitive stimulation with a serotype (KTH-1) of a gram-positive bacterium, Streptococcus sanguis. Eur J Immunol 1994; 24 : 1536-43.

8 Hirohata S, Hashimoto T. Abnormal T cell responses to bacterial superantigens in Behçet's disease. Clin Exp Immunol 1998;1 12:17-24.

9 Aoki K, Ohno S. Studies on the constitution and past history of patients with Behçet's disease. Acta Soc Ophtalmol Jpn 1972;76:1608-12.

10 Lellouche N, Belmatoug N, Bourgoin P, Logeart D, Acar C, Cohen-Solal A, et al. Recurrent valvular relacement due to exacerbation of Behçet's disease by Streptococcus agalactiae infection. Eur J Int Med 2003;14:120-2.

11 Suga Y, Tsuboi R, Kobayashi S, Ogawa H. A case of Behçet's disease aggravated by gingival infection with methicillin-resistant Staphylococcus aureus. Br J Dermatol 1995;133:319-21.

12 Diri E, Mat C, Hamuryudan V, Yurdakul S, Hizli N, Yazici H. Papulopustular skin lesions are seen more frequently in patients with Behçet's syndrome who have arthritis: a controlled and masked study. Ann Rheum Dis 2001;60:1074-6

13 Tunc R, Keyman E, Melikoglu M, Fresko I, Yazici $H$. Target organ associations in Turkish patients with Behcet's disease: a cross sectional study by exploratory factor analysis. J Rheumatol 2002;29:2393-6.

14 Lehner T, Lavery E, Smith R, van der Zee R, Mizushima $Y$, Shinnick T. Association between the 65-kilodalton heat shock protein, Streptococcus sanguis, and the corresponding antibodies in Behçet's syndrome. Infect Immun $1991 ; 59: 1434-41$.

\section{Different threshold for prolactin response to hypoglycaemia in patients with rheumatoid arthritis?}

In this issue of the Annals Eijsbouts and coworkers $^{1}$ show that the prolactin (PRL) response to hypoglycaemia is lower in patients with early untreated rheumatoid arthritis (RA) than in healthy controls Furthermore, the unique design of their study allowed the authors to compare the PRL response before the test, after 2 weeks of treatment with a non-steroidal anti-inflammatory drug (NSAID) and, then again, after 6 months of conventional antirheumatic treatment with NSAIDs and disease modifying antirheumatic drugs (DMARDs). After 6 months they found that the PRL response to hypoglycaemia was significantly normalised, which correlated positively with the Disease Activity Score. The results of the study $^{1}$ suggest that disease activity and/or treatment with DMARDs significantly affects the central regulation of PRL secretion resulting from stimulation in patients with RA.

A possible involvement of PRL in the pathogenesis of inflammatory diseases has been intensively studied, including a hypothesis about dysregulated secretion of this pituitary hormone in patients with RA. ${ }^{2}$ It has been shown that about one third of patients with RA are hyperprolactinaemic under basal conditions. ${ }^{2}$ However, controversy remains about whether stimulated secretion of PRL is up regulated or down regulated. Using the same stress stimulus as in the study of Eijsbouts et al, ${ }^{1}$ we showed that the PRL response to hypoglycaemia was decreased in 38 patients with long term RA with moderate disease activity who were receiving treatment with NSAIDs or DMARDs. ${ }^{3}$ In line with others, ${ }^{45}$ we observed a PRL response to thyrotropin releasing hormone stimulation comparable to the response in healthy subjects in the same cohort of patients, ${ }^{3}$ suggesting a normal pituitary gland but altered central neuroendocrine regulatory mechanisms in patients with moderately active RA. The disease activity rather than the treatment itself seems have a more important effect on the PRL response to hypoglycaemia.

The PRL response to insulin-induced hypoglycaemia, unlike that of other pituitary hormones (for example, growth hormone), is not usually triggered in all healthy subjects, at least in a dose of $0.1 \mathrm{IU} / \mathrm{kg}$ of rapid acting insulin and may depend on an individual person's threshold for PRL release. ${ }^{6}$

In our most recent study we observed a lower PRL response to hypoglycaemia in glucocorticoid naive premenopausal patients with RA. When we analysed the data we found during hypoglycaemia that a double or higher increase of plasma PRL occurred only in $5 / 15(33 \%)$ patients with RA but in $8 / 14$ $(57 \%)$ controls. PRL responses were irrespective of any clinical (disease activity, disease duration) or biochemical (tumour necrosis factor $\alpha$, interleukin $6, \mathrm{C}$ reactive protein, erythrocyte sedimentation rate) variables. The prevalence of PRL responders was not significantly different in patients with RA and controls, probably owing to the small sample size; however, the area under the response curve of PRL in patients with RA was significantly lower than in healthy controls. $^{7}$ Nevertheless, we suggest that patients with RA may have a tendency towards a higher threshold for PRL release in response to hypoglycaemia, which deserves further investigation.

To test our proposal we would be interested in having the authors' view of their data in patients with RA and finding out whether the improvement in the PRL response in their study $^{1}$ was due to a quantitatively higher response in individual patients or rather a qualitative shift from being a PRL nonresponding subject to a PRL responding subject.

Imrich, M Vigas

Institute of Experimental Endocrinology, Slovak Academy of Sciences, Bratislava, Slovakia

National Institute of Rheumatic Diseases, Piestany,

Slovakia

Correspondence to: Dr R Imrich, Institute of Experimental Endocrinology, Slovak Academy of Sciences, Vlarska 3, 83306 Bratislava, Slovakia; richard.imrich@savba.sk

\section{References}

1 Eijsbouts AM, Van Den Hoogen FH, Laan RF, Sweep FC, Hermus AR, Van De Putte LB. Decreased prolactin response to hypoglycaemia in patients with rheumatoid arthritis: correlation with disease activity. Ann Rheum Dis 2005 64:433-7, doi:10.1136/ard 2002.001347 [Published Online First: 19 August 2004].

2 Walker SE, Jacobson JD. Roles of prolactin and gonadotropin-releasing hormone in rheumatic diseases, Rheum Dis Clin North Am 2000;26:713-36.

3 Rovensky J, Bakosova J, Koska J, Ksinantova L, Jezova D, Vigas M. Somatotropic, lactotropic and adrenocortical responses to insulin-induced hypoglycemia in patients with rheumatoid arthritis. Ann N Y Acad Sci 2002;966:263-70.

4 Gutierrez MA, Garcia ME, Rodriguez JA,

Mardonez G, Jacobelli S, Rivero S

Hypothalamic-pituitary-adrenal axis function in patients with active rheumatoid arthritis: a controlled study using insulin hypoglycemia stress test and prolactin stimulation. J Rheumatol 1999;26:277-81.

5 Templ E, Koeller M, Riedl M, Wagner O, Graninger W, Luger A. Anterior pituitary function in patients with newly diagnosed rheumatoid arthritis. Br J Rheumatol 1996;35:350-6.

6 Cohen MP, Gala RR. Failure of insulin hypoglycemia to produce rise in serum prolactin. Am J Obstet Gynecol 1975;121:1 103-6.

7 Rovensky J, Imrich R, Malis F, Zlnay M, Macho L, Koska J, et al. Prolactin and growth hormone responses to hypoglycemia in patients with rheumatoid arthritis and ankylosing spondylitis. J Rheumatol 2004;31:2418-21.

\section{Authors' reply}

We thank the authors for their interest in our work and opportunity for discussion of this interesting but still puzzling subject. Published reports are contradictory, possibly because of different study subjects, different methods of stimulating prolactin (PRL) secretion, and large variation of PRL levels between individual subjects.

Indeed the study mentioned by the authors $^{1}$ showed that about one third of patients with rheumatoid arthritis (RA) were hyperprolactinaemic under basal conditions, and in our article we refer to other studies reporting hypersecretion of prolactin in RA. However, by now we have performed three studies in which we could not confirm this: (a) the study that is now being discussed, including a total of 50 patients with RA; $(b)$ a former smaller study in patients before and after undergoing total hip replacement, ${ }^{3}$ in which 10 patients with RA were compared with patients with osteoarthritis; and (c) a study in which we treated nine patients with RA with quinagolide, a dopamine agonist, which suppresses PRL secretion. ${ }^{4}$ None of these patients had raised PRL levels under basal conditions.

In our current study, ${ }^{2}$ 17/20 (85\%) healthy subjects had a double or higher increase in PRL levels in response to hypoglycaemiainduced stress, unlike the findings of the authors in their study, who found that only $57 \%$ of controls had a double or higher increase of PRL. They found PRL responses in patients with RA irrespective of disease activity, whereas in our study, as mentioned in the article, we found a negative correlation of PRL response and disease activity (DAS). We agree with the authors that it seems likely that disease activity is a more important factor in the changed PRL response than the treatment itself.

To answer the last question of the authors. In patients with RA we found that eight $(40 \%)$ patients did not show a double or higher increase of PRL levels, and after treatment for 6 months only four did not show such a response, which could be consistent with the suggestion of Dr Imrich that more patients become PRL responding. However, 15/20 patients showed a marked increase in PRL levels after 6 months in response to hypoglycaemia-induced stress, and so we conclude that the improvement of the PRL response that we observed was 
due to a general quantitatively higher response in most patients, and not a shift towards more patients being PRL responding.

A M M Eijsbouts on behalf of the other authors Department of Rheumatology, University Medical Centre, Nijmegen, PO Box 9101, $6500 \mathrm{HB}$ Nijmegen, The Netherlands

Correspondence to: Dr A M M Eijsbouts; a.eijsbouts@ maartenskliniek.n

\section{References}

1 Walker SE, Jacobson JD. Roles of prolactin and gonadotropin-releasing hormone in rheumatic diseases. Rheum Dis Clin North Am 2000;26:713-36.

2 Eijsbouts AM, Van Den Hoogen FH, Laan RF, Sweep FC, Hermus AR, Van De Putte LB. Decreased prolactin response to hypoglycaemia in patients with rheumatoid arthritis: correlation with disease activity. Ann Rheum Dis 2005; 64:433-7, doi:10.1136/ard.002.001347 [Published Online First: 19 August 2004].

3 Eijsbouts A, van den Hoogen F, Laan R, de Waal Malefiit M, Hermus A, Sweep C, et al. Similar response of adrenocorticotrophic hormone, cortisol and prolactin to surgery in rheumatoid arthritis and osteoarthritis. Br J Rheumatol 1998;37:1138-9.

4 Eijsbouts A, van den Hoogen F, Laan R, Hermus A, Sweep C, van de Putte L. Treatment of rheumatoid arthritis with the dopamine-agonist quinagolide. J Rheumatol 1999;26:2284-5.

A costly therapeutic dilemma in tophaceous gout: is etanercept or rasburicase preferable?

Tausche et al described a case of severe tophaceous gouty arthritis, which was treated with etanercept. ${ }^{1}$ They showed that antitumour necrosis factor $\alpha(\mathrm{TNF} \alpha)$ treatment can reduce the incidence of gouty attacks, which corresponds with the observation that $\mathrm{TNF} \alpha$ is activated in patients with gouty arthritis. ${ }^{2}$ Clearly, this is a costly symptomatic approach that is only in addition to the main treatment, which is lowering the serum uric acid (SUA) level in order to deplete urate depots and prevent gouty attacks and joint damage in the long term.

In the case presented, uricosuric treatment could only lower SUA levels from $0.58 \mathrm{mmol} /$ $\mathrm{l}$ to $0.56 \mathrm{mmol} / \mathrm{l}$ despite high doses of $2-3 \mathrm{~g}$ probenecid a day. This is in contrast with our experience. In our population of $95 \%$ undersecretors (defined as uric acid excretion in urine $<6.0 \mathrm{mmol} /$ day during normal diet) monotherapy with probenecid $500 \mathrm{mg}$ twice daily lowers SUA levels by 35\% (mean (SD) $0.17(0.05) \mathrm{mmol} / \mathrm{l})$, whereas probenecid $500 \mathrm{mg}$ twice daily in combination with allopurinol $200 \mathrm{mg}$ daily lowers SUA levels by $48 \%(0.27(0.08) \mathrm{mmol} / \mathrm{l})$ in patients with an adequate renal function (endogenous creatinine clearance $>50 \mathrm{ml} / \mathrm{min}$ ).

In the case presented by Tausche et al we would like to suggest another option for treating patients with severe tophaceous gout-that is, treatment with rasburicase. This recombinant form of urate oxidase very effectively metabolises uric acid in allantoin, which dissolves readily and is excreted by urine. So far one patient has been treated by applying rasburicase and urate depots were readily depleted (Moolenburgh JD et al, submitted paper)

In our opinion, for a case of severe tophaceous gout, when an expensive treatment is indicated, rasburicase should be considered as a potentially very effective treatment before using anti-TNF $\alpha$.

M K Reinders, E N van Roon, J R B J Brouwers Department of Clinical Pharmacy and Pharmacology, Medical Centre Leeuwarden, Henri Dunantweg 2, Leeuwarden, The Netherlands

T L Th A Jansen

Department of Rheumatology, Medical Centre Leeuwarden, Leeuwarden, The Netherlands

Correspondence to: Mr M K Reinders; m.reinders@znb.nl

\section{References}

1 Tausche AK, Richter K, Grässler A, Hänsler S, Roch B, Schröder HE. Severe gouty arthritis refractory to anti-inflammatory drugs: treatment with anti-tumour necrosis factor $\alpha$ as a new therapeutic option. Ann Rheum Dis 2004;63:1351-2.

2 McNearney T, Baethge BA, Cao S, Alam R Lisse JR, Westlund KN. Excitatory amino acids, TNF-alpha, and chemokine levels in synovial fluids of patients with active arthropathies. Clin Exp Immunol 2004;137:621-7.

\section{Authors' reply}

Like Reinders et al, we have found that in the defined "normal" population of undersecretors, conventional treatment effectively lowers serum uric acid (SUA) levels to the norm.

In those critical cases of severe tophaceous gout, as presented by us, the multiple tophi in the tissue and joints contain around $50 \mathrm{~g}$ or more uric acid. Despite the escalation of antihyperuricaemic (uricosuric and uricostatic) drugs, the SUA levels cannot be lowered significantly because of uric acid mobilisation from these depots and secondary shift to the serum.

Therefore, measurement of SUA levels alone does not verify the efficiency of treatment. ${ }^{1}$ In view of our own experience (unpublished data), we agree with Reinders et al that the recombinant urate oxidase rasburicase should be introduced into the treatment of severe tophaceous gout if conventional uric acid lowering treatment is not effective or contraindicated. These cases are extremely rare and occur in under $0.01 \%$ of the population of undersecretors.

There are two principles in the treatment of gout: firstly, uric acid lowering treatment with uricostatic and uricolytic agents and, secondly, anti-inflammatory treatment of gouty attacks. Both of these treatment regimens should follow a "step scheme". ${ }^{1}$

In the uric acid lowering treatment rasburicase might rank as the last step in treatment of patients with tophaceous gout. When gouty arthritis is refractory to treatment (with non-steroidal anti-inflammatory drugs, steroids, opioids) it is useful to introduce tumour necrosis factor $\alpha$ (TNF $\alpha$ ) blockade, as we showed in the published case. Because two different principles of action can be followed there seems to be no need to answer the question of priority of one of these treatments. Rasburicase should not be considered before TNF $\alpha$ blockade but, rather, the two should be combined if conventional treatment is not sufficient.

The main dilemma of both treatments in the first instance is not the high cost but the missing approval by the FDA in severe tophaceous gout. ${ }^{2}$ Unfortunately, valid data are lacking, for instance, about the best way of application (dosage, application interval) owing to the absence of clinical studies. Shortly after infusion of rasburicase instant uric acid metabolisation with abrupt decrease of SUA is observed. The resultant shift of uric acid from tissues to blood may cause a higher intensity of gouty attacks, and as we observed in one patient with urate nephropathy the worsening of renal function. ${ }^{3}$ We are very interested to learn of the article proposed by Moolenburgh et al.

A-K Tausche, H E Schröder Section of Internal Medicine, Department of Rheumatology, University Clinic Carl Gustav Carus, Dresden University of Technology, Germany

Correspondence to: Dr A K Tausche; anne-kathrin. tausche@mailbox.tu-dresden.de

\section{References}

1 Thiele $\mathbf{P}$, Schröder HE, Runge E. The treatment of essential hyperuricemia in graduated programs. Z Arztl Fortbild 1984;78:487-91.

2 Pui CH, Mahmoud HH, Wiley JM, Woods GM, Leverger G, Camitta B, et al. Recombinant urate oxidase for the prophylaxis or treatment of hyperuricemia in patients with leukemia or lymphoma. J Clin Oncol 2001;19:697-704.

3 Steele TH. Hyperuricemic nephropathies. Nephron 1999;81:45-9.

\section{CORRECTION}

doi: 10.1136/ard.2003.017087corr I

Prevalence and determinants of one month hand pain and hand related disability in the elderly (Rotterdam study) (Dahaghin S, Bierma-Zeinstra S M A, Reijman M, Pols H A P, Hazes J M W, Koes B W. Ann Rheum Dis 2005;64:99-104.)

We regret that table 5 of this paper mentioned on p 101 was omitted. This can now be found on the web at http://www. annrheumdis.com/supplemental

Corrections printed in the journal also appear on the Annals website http://www. annrheumdis.com and are linked to the original publication

\section{FORTHCOMING EVENTS}

Future events can be found on the website at http://annrheumdis.com 